\title{
KARAKTERISTIK MINERALOGI TANAH ENDAPAN PYROCLASTICS SURGE DI LERENG GUNUNGAPI LAMONGAN, JAWA TIMUR
}

\author{
Brilian Budi Prakosa \\ Program Studi Teknik Sipil, Universitas Sebelas Maret \\ Jalan Ir. Sutami 36 A, Surakarta \\ Email: brilianbudi@staff.uns.ac.id
}

\begin{abstract}
Pyroclastic surge deposits are often associated with both phreatomagmatic and preatic eruptions, which involve the presence of surface and subsurface water. In Indonesia, the identified pyroclastics surge deposits are on the slopes of Lamongan Volcano. This study aims to determine the mineralogical characteristics of sedimentary soils of this type, as well as to determine the depositional mechanism process that occurs at the time of formation of this material. The method used in this research is geological mapping of the research area, macroscopic physical observation, then petrographic analysis and SEM EDX to determine the mineralogical composition as well as to determine the type of eruption and its depositional mechanism. The geological conditions in the study area have mountainous morphology and volcanic hills with steep slopes, the lithology is predominantly composed of volcanic deposits resulting from the eruption of Lamongan Volcano with andesite, basalt, and sediment from the Maar eruption. The mineralogical composition of the constituent rocks based on petrographic analysis and SEM-EDX is dominated by andesine type plagioclase, hyperstene orthopyroxene, and clinopyroxene augite as phenocrysts, and for its basic mass composed of plagioclase microlites, opaque minerals (magnetite), and volcanic glass. The type of maar or ranu-forming eruption around the Lamongan Volcano is a phreatomagmatic type, as evidenced by its physical appearance and rock structure which indicates a significant influence of water and low density flows.
\end{abstract}

Keywords: Proclastics surge, minaralogy characteristics, volcano

\begin{abstract}
Abstrak
Endapan seruakan piroklastik (pyroclastics surge) seringkali berasosiasi dengan erupsi preatomagmatik dan preatik yang banyak melibatkan adanya air permukaan dan bawah permukaan. Di Indonesia, endapan seruakan piroklastik yang sudah teridentifikasi salah satunya berada di lereng Gunungapi Lamongan. Penelitian ini memiliki tujuan untuk mengetahui karakteristik mineralogi dari tanah endapan jenis tersebut, selain itu juga bisa untuk mengetahui proses mekanisme pengendapan yang terjadi pada saat pembentukan material ini. Metode yang digunakan dalam penelitian ini adalah pemetaan geologi daerah penelitian,pengamatan fisik makroskopik, kemudian dilakukan analisis petrografi dan SEM EDX untuk mengetahui komposisi mineraloginya sekaligus untuk mengetahui tipe erupsi maupun mekanisme pengendapannya. Kondisi geologi di daerah penelitian mempunyai morfologi pegunungan dan perbukitan vulkanik berlereng terjal, litologinya dominan tersusun oleh endapan vulkanik hasil erupsi Gunungapi Lamongan dengan jenis batuan andesit, basalt, serta endapan hasil letusan maar. Komposisi mineralogi batuan penyusunnya berdasarkan analisis petrografis dan SEM-EDX didominasi oleh plagioklas tipe andesin, ortopiroksen hipersten, dan klinopiroksen augit sebagai fenokris, serta untuk massa dasarnya tersusun oleh mikrolit plagioklas, mineral opak (magnetit), dan gelas vulkanik. Tipe erupsi pembentuk maar atau ranu di sekitar Gunungapi Lamongan adalah jenis freatomagmatik, dibuktikan dari kenampakan fisik dan struktur batuannya yang mengindikasikan adanya pengaruh air yang signifikan dan aliran berdensitas rendah.
\end{abstract}

Kata Kunci : Seruakan piroklastik, mineralogi, gunungapi

\section{PENDAHULUAN}

Indonesia adalah salah satu negara di dunia yang banyak memiliki gunungapi aktif maupun tidak aktif, khususnya Pulau Jawa yang terletak pada busur subduksi Lempeng tektonik Indo-Australia dan Eurasia. Hal tersebut mengakibatkan banyaknya persebaran material hasil erupsi gunungapi baik berupa batuan atau endapan asli yang belum mengalami proses pelapukan, maupun tanah hasil lapukan produk gunung api tersebut. Produk erupsi gunung api menurut proses atau mekanisme pengendapannya dibedakan menjadi tiga, yaitu: piroklastik jatuhan (pyroclastics fall), piroklastik aliran (piroclastics flow) dan endapan seruakan piroklastik atau lebih sering disebut piroklastics surge. Endapan seruakan piroklastik umumnya terjadi akibat dari suatu letusan gunungapi, yang temudian teralirkan (mekanisme gabungan antara jatuhan piroklastik dan aliran piroklastik). Endapan ini seringkali berasosiasi dengan erupsi preatomagmatik dan preatik yang banyak melibatkan adanya air permukaan dan bawah permukaan.. Sebaran dari endapan ini juga seringkali lebih luas jika dibandingkan dengan tipe endapan piroklastik lainnya. Belum banyaknya penelitian yang membahas lebih lanjut mengenai karakteristik endapan piroklastics surge ini menjadi faktor utama peneliti untuk mendalami tipe endapan ini.

Di Indonesia, endapan seruakan piroklastik yang sudah teridentifikasi salah satunya ada di Gunung Lamongan, dimana di lereng gunung tersebut banyak terdapat kawah-kawah (dalam bahasa lokal disebut ranu). Gunung api maar-diatreme merupakan tipe gunung api terbanyak kedua yang muncul di permukaan bumi, umumnya ditemukan 
terletak di atas benua maupun kepulauan. Menurut Schieferdecker (1959), maar adalah suatu cekungan yang umumnya terisi air, berdiameter mencapai $2 \mathrm{~km}$, dan dikelilingi oleh endapan hasil letusannya. Gunung api maar yang cekungan kawahnya tidak berisi air disebut maar kering. Maar juga diartikan sebagai kerucut gunung api monogenesis yang memotong batuan dasar di bawah permukaan air tanah dan membentuk kerucut berpematang landai yang tersusun oleh rempah gunung api berbutir halus hingga kasar, mempunyai diameter kawah bervariasi antara $100-3000$ m, yang sering terisi air sehingga membentuk danau (Bronto, 2001; Cas \& Wright, 1988). Ranu Segaran dan danau kecil lain yang berada di sekitar Gunung Lamongan, Probolinggo, Jawa Timur merupakan bukti adanya perkembangan maar yang mengindikasikan adanya aktivitas magmatik dan kontak magma dengan air.

Lokasi penelitian terletak di Desa Segaran, Kecamatan Tiris, Probolinggo, Jawa Timur, tepatnya di sisi lereng timur Gunung Lamongan dengan ketinggian berkisar $1651 \mathrm{~m}$.

Penelitian ini memiliki tujuan untuk mengetahui karakteristik fisik dan mineralogi dari endapan maar jenis piroklastics surge di Ranu Segaran, dan Ranu-Ranu disekitarnya yang terdapat di daerah Tiris, Kabupaten Probolinggo, Jawa Timur. Selain itu juga bisa untuk mengetahui proses mekanisme pengendapan yang terjadi pada saat pembentukan material tersebut.

\section{METODE PENELITIAN}

Metode yang digunakan dalam penelitian ini adalah pemetaan geologi daerah penelitian, kemudian melakukan analisis petrografi untuk mengetahui komposisi mineraloginya serta analisis granulometri untuk mengetahui karakteristik distribusi ukuran butir yang ada di daerah penelitian, sekaligus untuk mengetahui tipe erupsi maupun mekanisme pengendapannya.

\section{HASIL DAN PEMBAHASAN}

\section{Pemetaan geologi (skala $1: 25.000)$}

Menurut geologi regional, daerah penelitian ini termasuk dalam produk Gunungapi Lamongan dan Gunungapi Argopuro yang berumur kuarter dimana litologinya terdiri dari: tuf halus-lapili, lahar, lava, breksi gunungapi, kemudian lava Lamongan yang bersifat andesit-basaltik, dan endapan vulkanik Argopuro (Qva) disisi kaki gunung bagian timur, yang terdiri dari: $t u f$, breksi gunungapi, lava dan lahar hasil erupsi Gunung Argopuro. Namun litologi yang menyusun daerah penelitian ini oleh peneliti dibedakan menjadi beberapa satuan yang didasarkan atas genesanya, yaitu satuan lava andesit, satuan piroclastics fall (piroklastik jatuhan), satuan piroclastics flow (aliran piroklastik), satuan piroclastics surge (seruakan piroklastik), dan satuan breksi lahar.

\section{Pengamatan fisik endapan seruakan piroklastik}

Endapan seruakan piroklastik cukup mudah dikenali di lapangan, karena umumnya membentuk struktur-struktur sedimentasi seperti gradasi normal, silangsiur, dan laminasi, meskipun beberapa lapisan endapan ini juga ada yang bersifat masif. Struktur-struktur sedimen tersebut dapat dijumpai saling berkombinasi dalam suatu section perlapisan batuan (lihat lampiran penampang stratigrafi). Selain itu pada beberapa lapisan endapan seruakan piroklastik juga terlihat adanya penjajaran (imbrikasi) butiran-butiran yang kasar (berukuran lapili - gravel).

Satuan ini melampar di sekeliling kawah maar meluas searah dengan kemiringan lereng, hal ini terkait dengan proses terbentuknya dimana endapan piroclastics surge berasal dari runtuhan kolom erupsi maar yang bercampur air dan mengalir keluar dari kawah maar ke segala arah menuju tempat yang memiliki elevasi lebih rendah. Satuan ini terdiri dari litologi berupa endapan primer erupsi gunung api berukuran ash, lapili, dan fragmen bom, yang berwarna abuabu kecokelatan, belum terlitifikasi, menunjukkan sortasi baik, roundness fragmen butirnya berkisar angularsubangular, dan seringkali menunjukkan orientasi berlapis maupun struktur sedimen laminasi silangsiur yang lemah, hal ini menunjukkan mekanisme transport yang dominan dipengaruhi oleh adanya air.

Karakteristik sedimen yang akan dibahas berdasarkan tinjauan statisitik granulometri seperti perbandingan nilai rataan (mean), standar deviasi (sortasi), skewness, dan kurtosis. Unsur-unsur ini digunakan untuk menjelaskan tentang tekstur sedimen sampel yang diamati. Hasil analisis granulometri yang dilakukan pada endapan seruakan piroklastik pada Ranu Segaran, Katak, dan Ranu Kembar menunjukkan bahwa butiran penyusun endapan ini memiliki ratarata ukuran butir $0,9 \varnothing$ hingga $(-0,91 \varnothing)$ atau kurang lebih berkisar pada ukuran $1 / 2-2 \mathrm{~mm}$. Nilai standar deviasi dari sampel berkisar antara 1,11-1,69 dan termasuk dalam kategori tersortasi dengan buruk (poorly sorted) (Folk, 1974). Hal ini menunjukkan bahwa meskipun beberapa lapisan endapan seruakan piroklastik terlihat memiliki sortasi butir yang baik dilapangan, hasil perhitungan kuantitatif memperlihatkan lapisan endapan tersebut sesungguhnya 
memiliki sortasi butir yang relatif buruk. Dari perhitungan didapat nilai skewness keenam sampel yang diambil dari endapan ini bervariasi antara $0,61-2,55$. Semua nilai skewness yang diperoleh dengan cara matematis ini adalah positif. Hal ini berarti sedimen tersebut didominasi oleh pertikel yang berukuran tidak terlalu halus.

\section{Hasil Pengamatan Petrografis}

Analisis petrografi atau pengamatan melalui sayatan tipis batuan dimaksudkan untuk mengetahui data berupa tekstur batuan dan komposisi mineral penyusun batuan. Secara petrografis komposisi mineralogi pada sayatan tipis yang diambil dari beberapa maar di kompleks Gunungapi Lamongan memiliki kemiripan satu sama lain, yang membedakan hanya pada jumlah presentase kehadiran mineral pada tiap sayatan tipis, dan tekstur batuannya saja. Dari analisis sayatan tipis ini diketahui bahwa macam batuan yang menjadi fragmen dan ditemukan di lapangan, dimana jenisnya didominasi oleh batuan beku dengan komposisi andesitik, yaitu andesit, diorit, andesit piroksen dan bom.

Jumlah sayatan tipis yang diamati adalah sebanyak 16 sampel yang berasal dari empat maar di kompleks Gunung Api Lamongan, yang terdiri dari bom, blok lava, fragmen batuan dinding dan lava masif. Sampel-sampel tersebut memperlihatkan tekstur hipidiomorfik granular yaitu bentuk mineral didominasi bentuk subhedra, ukuran butirnya tidak seragam (inekuigranular), tesktur khusus terdiri dari intergranular, porfiritik, poikilitik, dan plagioklas yang memiliki kembaran zoning. Secara umum, komposisi mineral pada sayatan tipis terdiri dari fenokris berupa plagioklas, ortopiroksen, klinopiroksen dan mineral opak yang tertanam di dalam massa dasar berupa mikrolit plagioklas, mineral opak, dan mineral lempung. Pada Tabel 1. Memperlihatkan persentase kehadiran tiap mineral pada masing-masing sampel batuan. Secara petrografis komposisi mineralogi pada sayatan tipis yang diambil dari beberapa maar di kompleks Gunungapi Lamongan dapat diinterpretasikan sebagai berikut:

\section{Tekstur Batuan}

Pengamatan petrografi pada sayatan tipis menunjukkan keseluruhan sampel yang dianalisa merupakan andesit (Streckeisen, 1976). Tekstur yang berkembang adalah tekstur porfiritik dan porfiri dengan massadasar bertekstur vitrophyric (lihat lampiran petrografi). Fenokris yang hadir pada magma kompleks vulkanik Gunungapi Lamongan antara lain: plagioklas, hipersten, enstatite, augit, dan hornblende. Selain itu juga hadir mineral opak / oksida besi magnetit dengan kelimpahan tak lebih dari 10\%, ukuran fenokris berkisar 0,01-2,4 mm. Sedangkan massadasar sebagian besar berukuran halus yang tersusun oleh mikrolit plagioklas, piroksen, mineral opak, dan gelas vulkanik (lihat lampiran petrografi). Tekstur porfiritik terbentuk akibat terjadinya dua fase pada saat pendinginan magma. Fase pertama, magma mendingin secara lambat sehingga membentuk mineral-mineral yang berukuran lebih besar, sedangkan fase kedua magma mendingin secara cepat dan membentuk mineral-mineral yang berukuran lebih kecil (MacKenzie, dkk., 1982). Selain itu terdapat pula tekstur intergranular yaitu ruang antara potongan plagioklas ditempati oleh satu atau lebih mineral piroksen (ada atau tanpa olivin, dan mineral opak). Tekstur ini terbentuk akibat perbedaan waktu kristalisasi, dimana mineral piroksen akan mengkristal terlebih dahulu kemudian diikuti oleh mineral plagioklas yang mengkristal di sekelilingnya (MacKenzie, dkk., 1982). 
Tabel 1. Persentase kehadiran mineral pada tiap-tiap sampel sayatan tipis.

\begin{tabular}{|c|c|c|c|c|c|c|c|c|c|c|c|c|c|c|c|c|c|}
\hline \multirow{2}{*}{\multicolumn{2}{|c|}{ Nama Mineral }} & \multicolumn{16}{|c|}{ No. Sampel } \\
\hline & & $\begin{array}{c}\text { BBP } \\
01 \\
(\%) \\
\end{array}$ & $\begin{array}{c}\text { BBP } \\
02 \\
(\%) \\
\end{array}$ & $\begin{array}{c}\text { BBP } \\
03 \\
(\%) \\
\end{array}$ & $\begin{array}{c}\text { BBP } \\
05 \\
(\%) \\
\end{array}$ & $\begin{array}{c}\text { BBP } \\
06 \\
(\%) \\
\end{array}$ & $\begin{array}{c}\text { BBP } \\
12 \\
(\%) \\
\end{array}$ & $\begin{array}{c}\text { BBP } \\
10 \\
(\%) \\
\end{array}$ & $\begin{array}{c}\text { BBP } \\
11 \\
(\%) \\
\end{array}$ & $\begin{array}{c}\text { BBP } \\
13 \\
(\%) \\
\end{array}$ & $\begin{array}{c}\text { BBP } \\
14 \\
(\%) \\
\end{array}$ & $\begin{array}{c}\text { BBP } \\
15 \\
(\%) \\
\end{array}$ & $\begin{array}{c}\text { BBP } \\
07 \\
(\%) \\
\end{array}$ & $\begin{array}{c}\text { BBP } \\
08 \\
(\%) \\
\end{array}$ & $\begin{array}{c}\text { BBP } \\
09 \\
(\%) \\
\end{array}$ & $\begin{array}{c}\text { BBP } \\
04 \\
(\%) \\
\end{array}$ & $\begin{array}{c}\text { BBP } \\
16 \\
(\%) \\
\end{array}$ \\
\hline & & \multicolumn{6}{|c|}{ Ranu Katak } & \multicolumn{5}{|c|}{ Ranu Segaran } & \multicolumn{3}{|c|}{ Ranu Agung } & \multicolumn{2}{|c|}{ Ranu Kembar } \\
\hline \multicolumn{18}{|c|}{ Fenokris } \\
\hline 1. & Plagioklas & 45 & 25 & 50 & 30 & 20 & 5 & 30 & 25 & 35 & 30 & 20 & 50 & 45 & 30 & 40 & 30 \\
\hline 2. & Ortopiroksen & 20 & 14 & 20 & 20 & 8 & 10 & - & 10 & - & 5 & - & 10 & 40 & 20 & 18 & 20 \\
\hline 3. & Klinopiroksen & - & - & - & 4 & - & 5 & 20 & 25 & - & 15 & 20 & - & - & - & - & 5 \\
\hline 4. & Hornblende & - & - & - & - & - & - & - & - & - & - & - & - & - & 5 & - & - \\
\hline 5. & Mineral Opak & 5 & - & 5 & 10 & 2 & - & - & - & - & - & - & 5 & - & 5 & 10 & - \\
\hline 6. & Kuarsa & - & 1 & - & - & 2 & - & - & - & - & - & - & 1 & - & - & 2 & - \\
\hline 7 & Olivin & - & - & - & - & 5 & - & - & - & 5 & 5 & - & - & - & - & - & 5 \\
\hline \multicolumn{18}{|c|}{ Massa Dasar } \\
\hline 1. & $\begin{array}{l}\text { Mikrolit } \\
\text { plagioklas }\end{array}$ & 10 & 5 & 10 & 20 & 5 & 50 & 30 & 20 & 30 & 23 & 40 & 5 & 5 & 25 & 5 & 30 \\
\hline 2. & Mineral opak & 3 & 5 & 5 & 0 & 8 & 20 & 10 & 15 & 10 & 10 & 10 & 9 & 5 & 5 & - & 10 \\
\hline 3. & Piroksen & - & - & - & - & - & - & - & - & 5 & - & - & - & - & - & - & - \\
\hline 4. & Gelas vulkanik & 5 & 10 & 5 & 15 & 10 & 10 & 10 & 5 & 15 & 10 & 5 & 10 & - & - & 5 & - \\
\hline 5. & Mineral lempung & - & - & - & - & - & - & - & - & - & - & 5 & - & - & 5 & - & - \\
\hline 6. & Lubang & 2 & 40 & 5 & 1 & 40 & - & - & - & - & 2 & - & 15 & 5 & - & 20 & - \\
\hline
\end{tabular}

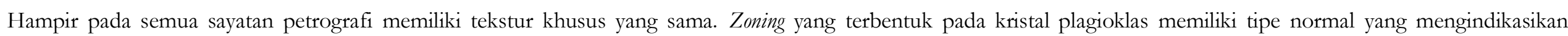

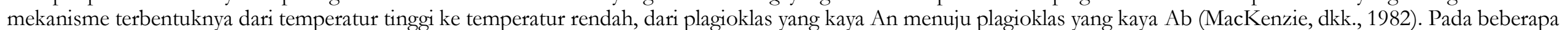
sampel (contohnya: BBP 14, 15, dan BBP 09) fenokris piroksen terdapat compositional zoning dan reaction rim pada tepi mineral.

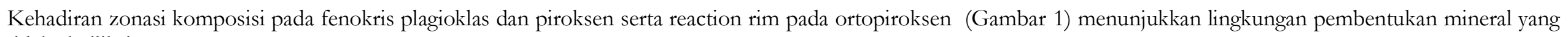
tidak ekuilibrium. 


\section{Komposisi Mineralogi}

Pengamatan dibawah mikroskop menunjukkan bahwa mineral sulung yang menyusun batuan di daerah penelitian terdiri atas plagioklas, ortopiroksen, klinopiroksen dan mineral opak, dengan massa dasar mikrolit plagioklas, gelas vulkanik, mineral opak dan mineral lempung hasil pelapukan.

\section{a. Plagioklas}

Plagioklas merupakan mineral yang memiliki komposisi terbanyak pada basalt, dengan rata-rata persentase pada tiap sampel $>50 \%$ (lihat Lampiran III). Plagioklas pada nikol sejajar tidak berwarna, sedangkan pada nikol bersilang plagioklas berwarna abu-abu, memiliki bentuk prismatik dengan hubungan antar butir subhedra, ukuran kristal berkisar antara $0.1-3 \mathrm{~mm}$ sebagai fenokris maupun massa dasar. Banyak dari plagioklas telah mengalami pelapukan, terlihat dari permukaan kristal yang rusak/jelek. Plagioklas memiliki kembaran yang bervariasi, diantaranya albit, carlsbad, albit-carlsbad, dan zoning (lihat Gambar 2). Zoning (zonasi) komposisi dari pusat ke tepian kristal di dalam plagioklas umum terjadi di batuan vulkanik yang terbentuk didaerah penunjaman, dimana zonasi tersebut dapat menggambarkan kondisi dan sejarah kristalisasinya.

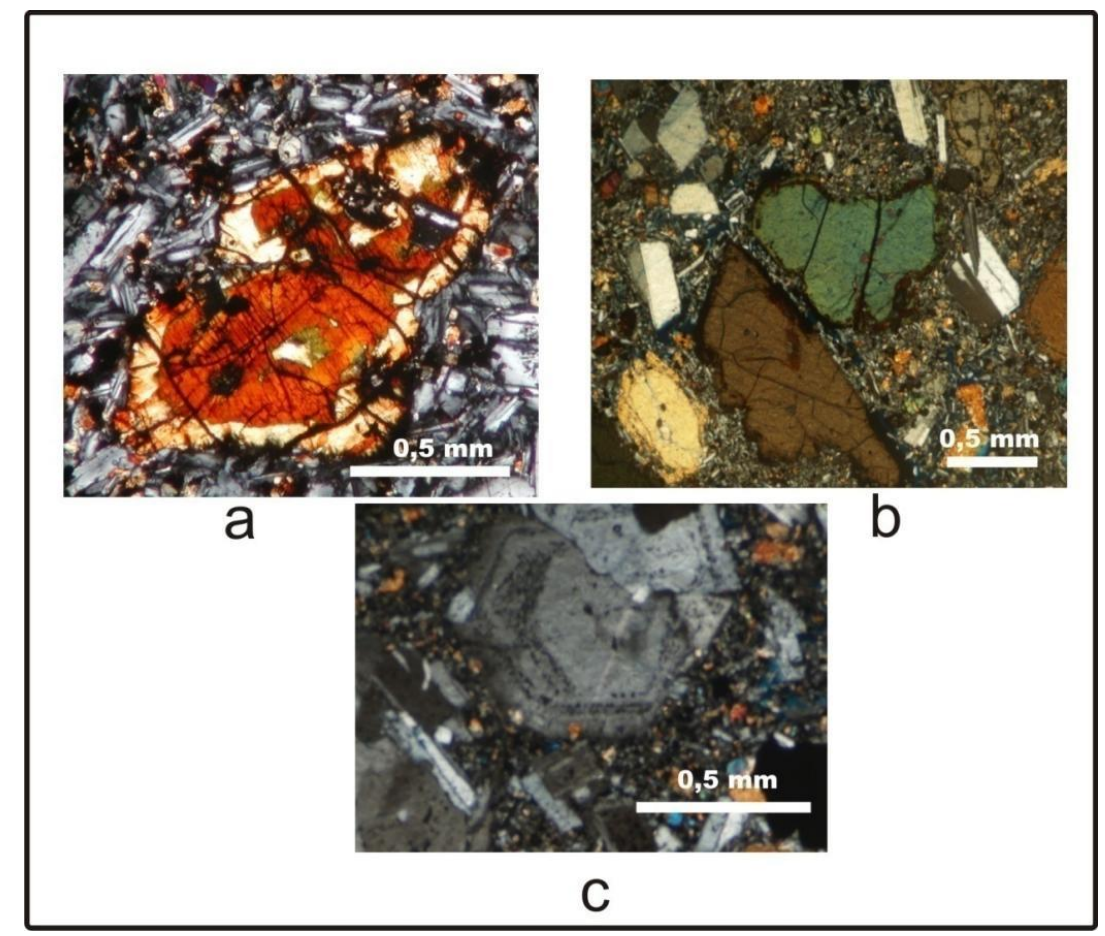

Gambar 1. Kenampakan dibawah mikroskop (a) compositional zoning pada ortopiroksen (b) reaction rim pada piroksen (c) compositional zoning pada plagioklas.

Zonasi yang berkembang pada komposisi plagioklas di dalam andesit yaitu tipe normal dimana plagioklas kaya An di pusat kristal ditandai dengan batas-batas zonasi yang tipis yang diikuti dengan semakin tajam batas-batas zonasi tersebut ke arah luar. Hal tersebut menjelaskan bahwa proses pendinginan terjadi secara perlahan pada bagian inti, kemudian terjadi penurunan kandungan An ke kaya Ab yang ditandai dengan pendinginan yang semakin cepat dan berkurangnya kandungan air pada bagian tepi plagioklas. Perbedaan kandungan An pada plagioklas tersebut menjelaskan mengenai proses kristalisasi fraksinasi, dimana larutan magma yang mengkristal di akhir akan berbeda dengan larutan magma yang terbentuk di awal, dengan kondisi tekanan yang berbeda pula. Jadi, tidak adanya reaksi kristal dengan larutan magma yang menyebabkan kristalisasi fraksinasi, pertumbuhan kristal plagioklas akan semakin menambah pengkayaan unsur albit di tiap lapisannya yang menandakan masuknya magma baru dengan komposisi yang sama ke dalam dapur magma. 

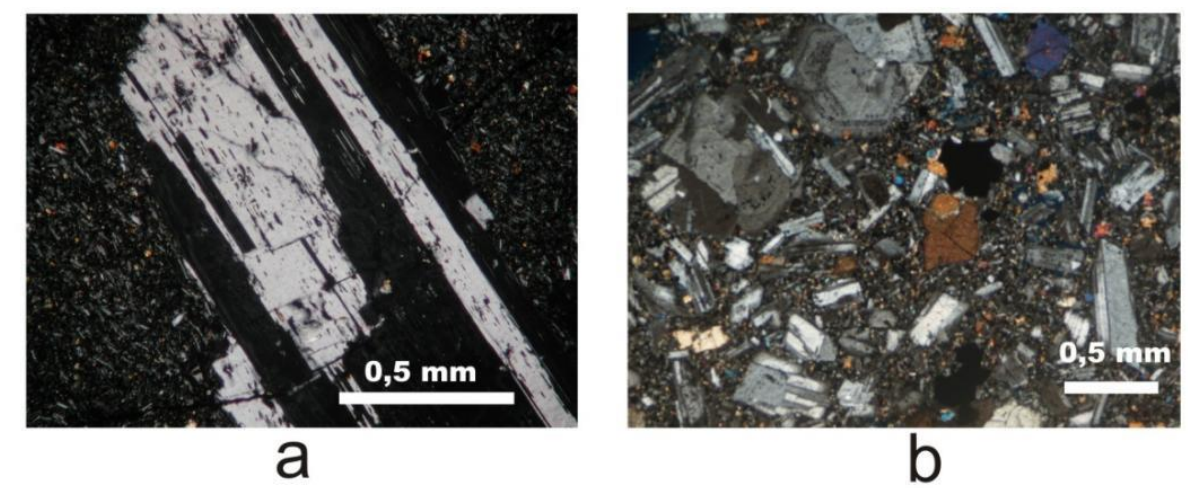

Gambar 2. Kenampakan dibawah mikroskop (a) kembaran carlsbad pada kristal plagioklas (b) kenampakan plagioklas yang menunjukkan zoning.

Sudut gelapan dari plagioklas berkisar antara 21.5 - 25 (jenis andesin) dan $31.5^{\circ}-34^{\circ}$ (jenis labradorit) Namun, sebagian besar plagioklas pada sayatan tipis basalt berjenis andesin. Jenis-jenis plagioklas tersebut memperlihatkan bahwa temperatur pembentukan batuan beku tersebut berkisar antara $\pm 900^{\circ} \mathrm{C}$. Plagioklas dengan jenis andesin biasa ditemukan dalam batuan beku intermediet, contohnya diorit dan andesit. Diorit dan andesit yang berasal dari magma intermediet dapat dihasilkan melalui proses percampuran magma (magma mixing) antara magma basaltik dan magma riolitik. Keterdapatan plagioklas berjenis andesin memperlihatkan bahwa magma pembentuk batuan telah mengalami perubahan dari magma primernya. Namun berdasarkan hasil analisis SEM-EDX satu sampel yaitu BBP 16 memiliki kandungan An71 dan masuk kedalam jenis bytownite, hal ini tergolong anomali dan menunjukkan asal mula parental magma yang bersifat basaltic, atau bisa juga akibat proses mixing antara kristal/ batuan yang terbentuk terlebih dahulu pada suhu tinggi, dengan magma intermediet yang mempuyai suhu lebih rendah.

\section{b. Piroksen}

Piroksen adalah mineral yang jumlah persentasenya dalam batuan terbanyak setelah plagioklas. Dalam sayatan tipis batuan, piroksen dapat dibedakan menjadi dua, yaitu ortopiroksen dan klinopiroksen. Di bawah mikroskop, klinopiroksen berwarna coklat pucat (nikol sejajar) dan hijau-biru kemerahan (nikol bersilang), bentuk subhedra euhedra, ukuran kristal berkisar antara $0.01-2 \mathrm{~mm}$, kedudukan gelapan miring dengan sudut gelapan umumnya berkisar antara $37^{\circ}-45^{\circ}$, sehingga masuk kedalam jenis augit (Kerr, 1959). Sedangkan, ortopiroksen di bawah mikroskop berwarna coklat muda (nikol sejajar) dan cokelat keemasan (nikol bersilang), bentuk subhedra euhedra, ukuran kristal antara $0.01-1.5 \mathrm{~mm}$, kedudukan gelapan sejajar dengan sudut gelapan $0^{\circ}$, tidak ada pleokroisme sampai lemah dan berwarna coklat, sehingga masuk kedalam jenis enstantit, selain itu ada pula yang lebih banyak dijumpai yaitu memiliki pleokroisme, dan masuk kedalam jenis hipersten (Kerr, 1959). Perbedaan antara jenis ortopiroksen jenis enstantit dan hipersten terletak pada perubahan warna pleokroisme, dimana pleokroisme pada hipersten akan berubah warna menjadi hijau atau coklat keunguan (Kerr, 1959).

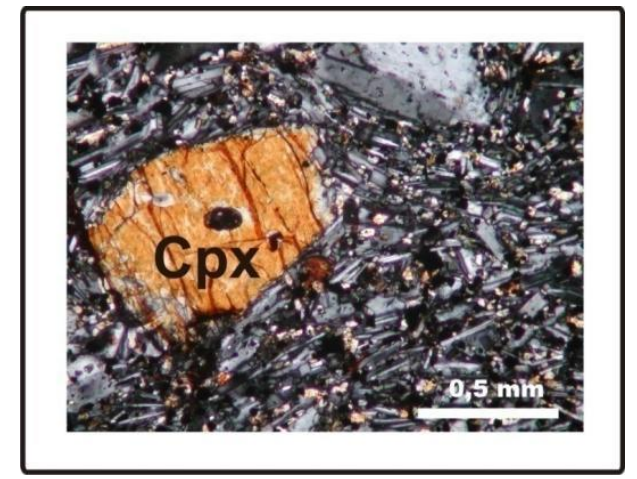

Gambar 3. Kenampakan dibawah klinopiroksen pada sampel BBP 16 Ranu Kembar. 
c. Mineral Opak

Mineral opak (lihat Gambar 4) di bawah mikroskop memberikan kenampakan warna hitam baik pada nikol sejajar, maupun nikol bersilang, memiliki bentuk anhedra, ukuran kristal $<0.01-0.5 \mathrm{~mm}$. Mineral opak dalam sayatan tipis batuan ini adalah magnetit $\left(\mathrm{Fe}_{3} \mathrm{O}_{4}\right)$ dan ini dibuktikan melalui analisis SEM-EDX, Mineral opak jenis lain seperti sulfida sebagai indikator mineralisasi tidak dijumpai, dan ini menunjukkan bahwa batuan-batuan di sekitar maar maupun yang menjadi batuan dinding dan ikut terlontarkan bersama erupsi masih dalam keadaan segar atau belum mengalami alterasi maupun mineralisasi.

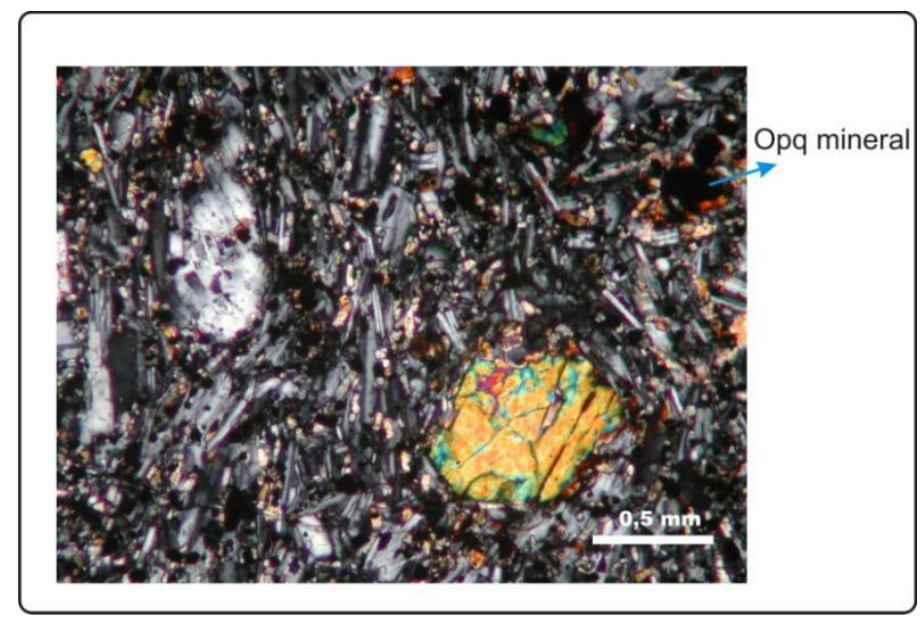

Gambar 4. Kenampakan mineral opak (opq) pada nikol bersilang pada sampel BBP 16.

\section{Hasil Analisis SEM-EDX}

Hasil analisis EDX (Tabel 2) menunjukkan komposisi kimia unsur/kation yang dinyatakan dalam \% berat. Untuk dapat digunakan dalam perhitungan rumus kimia mineral-mineral silikat, konsentrasi unsur-unsur penyusunnya tersebut harus diubah kedalam bentuk oksidanya dan tetap dinyatakan dalam \% berat. Data komposisi kimia tersebut kemudian dihitung dengan metode perbandingan proporsi mol dari kation (Klein, 2002) untuk mengetahui rumusan kimia pasti dari mineral yang ditembak.

Tabel 2. Hasil analisis SEM-EDX untuk mengetahui komposisi kimia mineral logam maupun silikatnya.

\begin{tabular}{|c|c|}
\hline Nomor Sampel & Mineral \\
\hline BBP 09 & $\begin{array}{l}\mathrm{Fe}_{3} \mathrm{O}_{4} \text { (Magnetite), } \\
\mathrm{Ca}_{0,80}\left(\mathrm{Mg}_{0,70}, \mathrm{Al}_{0,39}\right) \mathrm{Si}_{2} \mathrm{O}_{6} \text { (Augite) }\end{array}$ \\
\hline BBP 16 & $\begin{array}{l}\text { Plagioclase } \mathrm{Ab}_{29} \mathrm{An}_{71} \text { (Bytownite) } \\
\text { Olivine } \mathrm{FO}_{57} \mathrm{Fa}_{43} \text { (Forsterite) }\end{array}$ \\
\hline BBP 23 & $\begin{array}{l}\mathrm{Fe}_{3} \mathrm{O}_{4} \text { (Magnetite) } \\
\text { Olivine } \mathrm{F}_{78} \mathrm{Fa}_{22} \text { (Forsterite) }\end{array}$ \\
\hline BBP 13 & $\begin{array}{l}\mathrm{Ca}_{0,57}\left(\mathrm{Mg}_{0,55} \mathrm{Fe}_{0,63}\right) \mathrm{Si}_{2} \mathrm{O}_{6} \text { (Augite) } \\
\text { Olivine } \mathrm{FO}_{59} \mathrm{Fa}_{41} \text { (Forsterite) }\end{array}$ \\
\hline BBP 14 & $\begin{array}{l}\mathrm{Fe}_{3} \mathrm{O}_{4} \text { (Magnetite) } \\
\text { Olivine } \mathrm{FO}_{79} \mathrm{Fa}_{21} \text { (Forsterite) }\end{array}$ \\
\hline
\end{tabular}

Dari perhitungan tersebut diperoleh hasil bahwa mineral logam yang ikut menyusun batuan adalah magnetit, tidak didapati kehadiran mineral sulfida dalam sampel-sampel batuan tersebut. Hal ini mengindikasikan bahwa batuan dinding belum mengalami alterasi maupun mineralisasi apapun. Kemudian untuk jenis plagioklas yang terdapat pada sampel adalah jenis $\mathrm{Ab}_{29} \mathrm{An}_{71}$ (Bytownite). Pengamatan adanya zoning plagioklas apakah dia tipe zoning normal atau terbalik tidak bisa dilakukan secara langsung, karena keberadaan plagioklas yang mempunyai zoning tidak bisa diidentifikasi melalui sayatan poles. Namun adanya plagioklas berzoning dan plagioklas jenis andesin maupun labradorit yang diidentifikasi melalui sayatan tipis, mengindikasikan adanya dua kemungkinan, yaitu diferensiasi normal pada magma ataupun magma mixing. 
Selain peranan untuk mengetahui jenis mineral logam yang terkandung, dan jenis plagioklasnya, analisis SEM-EDX juga bisa digunakan untuk memperkuat hasil pengamatan petrografis, yaitu bisa mengetahui spesies mineralmineral silikat secara pasti melalui formula kimianya. Mineral silikat lain yang juga teridentifikasi lewat SEM-EDX ini adalah klinopiroksen jenis $\mathrm{CaO}_{57}\left(\mathrm{MgO}_{55} \mathrm{Fe}_{63}\right) \mathrm{Si}_{2} \mathrm{O}_{6}$ (Augite). Mineral olivin juga hadir dalam sampel batuan dan berjenis $\mathrm{FO}_{57} \mathrm{FO}_{79}$ (Forsterite).

\section{Interpretasi Mekanisme Pengendapan.}

Seruakan piroklastik (pyroclastic surge) diinterpretasikan sebagai aliran piroklastik yang memiliki konsentrasi partikel yang rendah. Rendahnya konsentrasi partikel menyebabkan seruakan piroklastik hanya mampu membawa butiran yang berukuran abu-lapili saja. Selain itu rendahnya konsentrasi partikel juga menyebabkan seruakan piroklastik mampu membentuk struktur-struktur sedimen saat tubuh seruakan piroklastik tersebut diendapkan. Proses pembentukan seruakan piroklastik sendiri diinterpretasikan terbagi menjadi dua mekanisme yang menghasilkan dua tipe endapan seruakan piroklastik yang berbeda. Tipe pertama adalah endapan seruakan piroklastik yang mempunyai struktur silang-siur dan laminasi. Endapan ini diinterpretasikan sebagai endapan ground surge (Cas \& Wright, 1987). Selain bergerak secara individu ground surge juga dapat mengiringi tubuh aliran piroklastk dimana ground surge terbentuk dibagian depan dari tubuh aliran piroklastik, sehingga endapan ground surge dapat dijumpai atau diendapkan dibawah endapan aliran piroklastik. Tipe kedua adalah endapan seruakan piroklastik yang mempunyai struktur gradasi normal dan masif. Endapan tersebut diinterpretasikan sebagai endapan ash-cloud surge (Cas \& Wright, 1987). Proses pembentukan ash-cloud surge sendiri berasosiasi dengan pembentukan tubuh aliran piroklastik (block and ash flow) dimana ash-cloud surge terbentuk pada bagian atas dari tubuh aliran piroklastik, sehingga endapan ash-cloud surge sering dijumpai diendapkan diatas endapan aliran piroklastik. Namun, pada beberapa kasus ash-cloud surge juga dapat memisahkan diri dari tubuh aliran piroklastik. Umumnya pemisahan ini disebabkan oleh pengaruh topografi, saat pergerakan aliran piroklastik tersebut terhalang oleh tebing / bukit, tubuh aliran piroklastik tersebut akan berhenti bergerak dan diendapkan, tetapi ash-cloud surge yang mengiringi aliran piroklastik tersebut masih mampu untuk bergerak bebas (kemungkinan disebabkan oleh rendahnya konsentrasi partikel) sehingga ash-cloud surge mampu terus bergerak melewati morfologi yang menghalanginya. Oleh karena itu sebaran seruakan piroklastik di daerah penelitian bisa lebih luas dan menutupi aliran piroklastik. Dalam kasus di lokasi lain, yaitu Gunung Merapi yang terletakdi perbatasan Jawa Tengan dan Daerah Istimewa Yogyakarta, endapan piroklastik surge bisa melampar sejauh $10 \mathrm{~km}$ dari celah magma (vent) atau $2 \mathrm{~km}$ lebih jauh dari BAF (block ash fall) yang identik dengan piroclastic flow (Cronin, dkk, 2013).

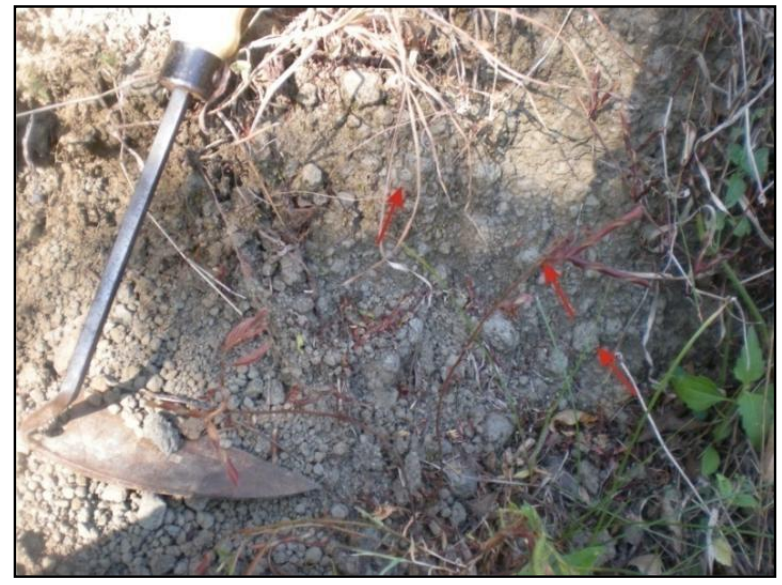

Gambar 5. Kenampakan accretionary lapili di lapangan sekitar Ranu Katak menunjukkan kondisi basah saat pengendapan.

Adanya kandungan butiran accretionary lapili pada beberapa lapisan endapan seruakan piroklastik menunjukkan bahwa kondisi lingkungan saat diendapkan seruakan piroklastik tersebut adalah jenuh air atau basah.

\section{SIMPULAN}

1. Kondisi geologi di daerah Kecamatan Tiris, Kabupaten probolinggo terletak pada morfologi pegunungan dan perbukitan vulkanik berlereng terjal, litologinya didominasi oleh endapan vulkanik hasil erupsi Gunung Api 
Lamongan dengan jenis litologi andesit dan basalt, serta endapan hasil letusan maar, dengan sebaran lokal disekeliling danau maar.

2. Komposisi mineralogi batuan penyusunnya bersdasarkan analisis petrografis dan SEM-EDX didominasi oleh plagioklas tipe andesin, ortopiroksen hipersten, dan klinopiroksen augit sebagai fenokris, serta untuk massadasarnya tersusun oleh mikrolit plagioklas, mineral opak (magnetit), dan gelas vulkanik.

3. Jenis erupsi pembentuk Maar Ranu Segaran dan sekitarnya adalah jenis freatomagmatik, dibuktikan dari adanya pengaruh air yang signifikan berdasarkan kenampakan accretionary lapili dan struktur silangsiur pada endapan seruakan piroklastik. Mekanisme pengendapan endapan seruakan piroklastik yang memiliki ukuran butir ratarata 0,5 - $2 \mathrm{~mm}$, dan poorly sorted adalah melalui arus dengan konsentrasi partikel rendah.

\section{UCAPAN TERIMAKASIH}

Ucapan terimakasih sebesar-besarnya diberikan kepada Prof. Koichiro Watanabe atas fasilitas yang diberikan kepada penulis di Laboratorium Georesources, Kyushu University. Dr. Agung Harijoko dan Prof. Toshiaki Hasenaka atas bimbingan langsung di lapangan.

\section{REFERENSI}

Carn, S.A.,1999, “The Lamongan Volcanic Field, East Java, Indonesia: Physical Volcanology, Historic Activity and Hazard", Journal of Volcanology and Geothermal Research. Vol.95, 81-108 p.

Carn, S.A., Pyle, D.M., 2001, "Petrology and Geochemistry of the Lamongan Volcanic Field, East Java, Indonesia: Primitive Sunda Arc Magmas in an Extensional Tectonic Setting?”, Journal of Petrology. Vol.42 No. 9, pp. 1643-1683 p.

Cas, R.A.F., Wright, J.V., 1987, "Volcanic Successions: Modern and Ancient”, Unwyn Hyman. London, 528 p.

Cronin, S.J., Gert Lube, Devi S. D., Sri .S., S. Subrandiyo, Surono., 2013,” Insights Into The October-November 2010 Gunung Merapi Eruption (Central Java, Indonesia) from The Stratigraphy, Volume and Characteristics of Its Pyroclastic Deposits", Journal of Volcanology and Geothermal Research. Vol.261, pp. 244-259 .

Klein, C., 2002, "The 22nd Edition of the Manual of Mineral Science", John Willey \& Sons Inc. New York.

Lorenz, V., 2006, "Syn - and Post Posteruptive Hazard of Maar-Diatreme Volcanoes", Journal Volcanology and Geothermal Research. Vol. 159, pp. 285-312

MacKenzie, W.S., Donaldson, C.H dan Guilford, C., 1982, “Atlas of Igneous Rock and Their Textures”, Longman. England

Middlemost, E.A.K., 1985, “Magmas and Magmatic Rocks, an Introduction to Igneous Petrology”, Longman. New York.

P.F. Kerr, 1977, “Optical Mineralogy 5th Edition”, Mc Graw-Hill Inc. pp. 492. 